Multidisciplinary

SCIENTIFIC JOURNAL OF

MARITIME RESEARCH

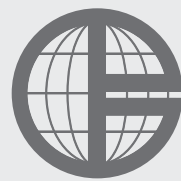

University of Rijeka

Faculty of Maritime

Studies Rijeka
Multidisciplinarni

znanstveni časopis

POMORSTVO

\title{
The Evaluation of the Efficiency of Transport and Logistics Infrastructure of Railway Transport
}

\author{
Karlygash Saparovna Mukhtarova ${ }^{1}$, Serik Sarsengalievich Ospanov ${ }^{1}$, \\ Madina Duzbaievna Sharapiyeva ${ }^{2}$, Alfonz Antoni ${ }^{3}$ \\ ${ }^{1}$ Al Farabi Kazakh National University, Almaty, 050038, al-Farabi ave., 71, Republic of Kazakhstan, e-mail: kmukhtarova@inbox.ru; Ospanov.serik@kaznu.kz \\ ${ }^{2}$ Al Farabi Kazakh National University, Alma-Ata's region, Talgar district, Guldala village, Aiteke bi street 39 index 041611 , Republic of Kazakhstan, \\ e-mail: Sh.mad@mail.ru \\ ${ }^{3}$ Budapest Metropolitan University, Budapest 1148. Nagy Lajos kir. Út 1.-9., Hungary
}

\section{ABSTRACT}

The high level of logistics development positively affects many socio-economic indicators of the country's economic development, such as inflation rates, productivity indicators, etc. Increasing productivity through the use of logistics at enterprises has a positive impact on the competitiveness in global markets, as well as on profit level. The aim of this article is to analyze the evolution of productivity in rail transport among several countries from 1997 to 2016. We use a non-parametric approach that allows us to change the performance and efficiency of the transport infrastructure. The main indicators of rail transport should be divided into variations of efficiency and technical changes. The results indicate that productivity growth is concentrated in the last period (1997-2016), when most countries conducted reform processes. This increase in productivity occurred mainly due to technical progress. We also analyze the correlation analysis to determine the factors most influencing the effectiveness. In contrast to similar articles, we justified that the higher the autonomy and financial independence, the higher the level of efficiency and technical change in the infrastructure of the railway transport.

\section{ARTICLE INFO}

Review article

Received 2 May 2018

Accepted 26 May 2018

\section{Key words:}

Efficiency

Correlation analysis

Productivity

Railways

\section{Introduction}

Transport and logistics infrastructure is a key element of the national economy, affecting the functioning of any industry, non-productive sphere. Therefore, its inefficient development is becoming a difficult barrier to economic growth in any single industry or in every region. These circumstances make special demands on the directions of the long-term development of the transport infrastructure both at the regional and federal levels. Therefore, the problem of increasing the efficiency of development and developing a long-term strategy for the innovative development of transport infrastructure is urgent and requires an early solution.

Transport and logistics infrastructure is a rapidly developing system in modern society. Playing a key role in the implementation of priority national projects and solving social problems, the transport infrastructure contributes to the activation of our country's participation in the economic processes of the world economy. Increase and intensification of interrelations in the process of transport infrastructure operation requires the introduction of innovative development principles, the application of which in various fields of activity allows to significantly reduce business costs and improve the quality of provided services. The innovative direction of the transport structure development contributes to the increase of the efficiency of the cargo transportation process, since in this case the general objectives of all the participants of the transport infrastructure, and not the individual goals of each participant, are taken separately.

One of the most analyzed topics in the literature on transport economics was testing hypotheses about the existence of economies of scale in the railway sector. The results of these studies were used to justify the regulatory system for railways. For this reason, regulators should support companies and prevent monopolistic behavior. Despite the fact that the results are not completely final, 
most studies exclude the existence of a scale of the economy, except for the smallest companies. Many of these studies were used to justify the deregulation of the sector. Simultaneusly, since the major restructuring of the sector, which began in many countries in the mid-1990s, there is a growing need to analyze the efficiency and productivity of companies in this sector. This analysis allows us to assess how the industry behaves during the regulatory period and the effectiveness of the first measures for deregulation. Despite the interest, the topic of railways has been little studied in the literature and articles. On the contrary, as it was already indicated, almost all attention has been paid to the analysis of the absence of scales, scales or network economies and much less to measuring what can be one of the main sources of difference in the average costs of companies: the so-called X-inefficiency.

From the literature on productivity and efficiency applied to the railway sector, an outstanding study made by Caves, Christensen and Swanson (1980), who described a simple procedure for estimating productivity growth based on an estimate of the cost function. The authors applied this technique to the model of American railway companies for 1955, 1963 and 1974, obtaining an average productivity gain of about 1.5\% [1]. Bereskin (Bereskin, 1996) estimated the cost function for the US group for the period 1978-93. The main conclusion was that the process of deregulation (beginning from 1980 with the use of Staggers Act) appeared to have a positive effect on the rate of productivity growth, as observed through shifts in the estimated cost function. It should be listed as it is recognized by Cavesetal (1982) that the estimated performance growth rates are very sensitive to the specification of the cost function. In addition, they do not use the borderline approach, but consider the middle functions. However, from a theoretical point of view, the concept of the scale of the economy and technical changes are applicable only to the final boundary [5].

In order to ignore the possible existence of ineffective behavior, the problem is inherent in all studies that use average functions, not only represents a conceptual problem, but can also seriously affect the assessment of large-scale economic changes, as they would be biased in the presence of inefficiency.

\section{Background}

The first study using border technology to analyze the efficiency of the rail road sector was carried out by Perelman and Pestio (2002). They use a deterministic boundary, requiring that a priori imposing of a functional form for the boundary [2]. More recently, Oumand Yu (1994) evaluated the productive efficiency of railway companies using non-parametric methods (Dataenvelopmentanalysis, Data Coverage Analysis). Their analysis focuses on the effectiveness of the determinants, among which they emphasize the degree of financial and autonomy of management. However, they do not analyze performance, technical changes, or its determinants.
These studies are also subject to problems inherent in parametric approaches, and in this sense both the efficiency levels and the rates of evaluation of technical changes depend crucially on the functional specification chosen and on the assumptions about the distribution of the error. In addition, to assess the boundaries of production, authors need to combine different results of the industry, thus not allowing them to take advantage of specialization for certain results[4].

Finally, Cowie and Readington (1996) analyzed the effectiveness of the European railways in 1992. Their analysis is focused on comparing the results obtained with different border approaches. However, dynamic changes are not analyzed. The main conclusion is that an accurate measurement of efficiency is not possible, but the results may indicate good and bad performers[3].

In our study, unlike Cavesetal (1985) and Bereskin (1996), we use a correlation analysis of the performance of rail transport, its productivity of railway companies. For this purpose, we use the concept of General Factor Productivity (TFP)[6][7]. This indicator will be measured using a correlation analysis of productivity, calculated using statistics on railway companies. This procedure has the advantage compared to the studies of other scientists.

\section{Methodology and Resources}

Fedorov V.N. (2000) in his research proposed the stages of evaluation and analysis of infrastructure development. Considering those stages, we in the course of the study developed the procedure for applying the methods of assessing the efficiency of the railway transport infrastructure.

Stage 1. Formation of the concept and indicators of assessing the effectiveness of the infrastructure

Stage 2. Study of the influence of the main indicators of the railway infrastructure on economic growth (gross domestic product).

Stage 3. Defining criteria and system of assessing the effectiveness of infrastructure provision

Stage 4. Proposal to the application of the composite indicator of the effective evaluation of the railway transport infrastructure

Stage 5. Investigation of the efficiency of the transport infrastructure component

Step 6. Identifying factors that affect the efficiency of infrastructure provision

Stage 7. Modeling of multifactor dependence of infrastructure efficiency

Stage 8. Obtaining and analyzing the results of a multicriteria and multi-faceted assessment of the efficiency of the railway infrastructure [9][10].

Sibirskaya E.V. (2013) Any organization or business, implementing logistics and forming a logistics system, tries to assess its actual or potential efficiency. During the development of logistics in developed countries, a system of indicators has been formed, assessing its efficiency and 
effectiveness. Here is a brief analysis of these complex indicators.

In general terms, assessing the efficiency and effectiveness of rail transport can include the following indicators:

1. Passenger turnover (number of people);

2. Goods turnover (tons);

3. Number of locomotives;

4. Number of workers (laborious workers in this infrastructure);

5. Length of operational roads.

These indicators can be called key or integrated indicators of the effectiveness of the railway infrastructure. They are the basis of reporting forms of companies and systems of indicators of logistics plans of different levels.

Over the past decade, logistic costs of many Western companies have increased in logistical functions such as transportation, order processing, information and computer support, and logistics administration [11].

A well-known American logistics consultant, Herbert W. Davis, for several years investigated the logistics costs in the US industry for warehousing, transportation, order management / customer service, distribution management, and inventory management as an integral part of the final price of products and consumer services.

In 2013, for example, the structure of logistics costs, expressed in shares (\%) of sales, was as follows: transportation of finished commodities $-4.08 \%$; warehousing-2.40; management of customer service / orders-0.55; distribution control-0.36; the cost of storing stocks (at 18\% discount rate) $-1.81 \%$ - a total of $9.02 \%$. The cost structure (in dollars per hundred pounds of product weight): transportation of finished commodities-13.24; warehousing-10.79; management of customer service / orders $-4,07$; distribution control-2.53; and the cost of storing stocks at an $18 \%$ discount rate of $-18,13$. The total amount was 47,48 [12].

Lakshmanan T., Andersen W. (2002) identified the most important complex indicators of the efficiency of the logistics system. The basis of this - is the duration of the complete logistics cycle - the time for the execution of the customer's order. The use of this indicator (or its individual components) is conditioned by the requirements of the corporate strategy, if time is chosen as the main factor of increasing the competitiveness of the firm [13].

The complex indicator - the productivity (efficiency) of the logistics system - is determined by the volumes of logistic work (services) performed by technical means, technological equipment or personnel involved in the logistics system, per unit time, or unit costs of resources in the logistics system.

In most foreign firms with logistics services, special reports on logistic productivity / productivity are compiled, which reflect a sufficiently large number of indicators, for example:

- the number of orders processed per unit of time;

- cargo shipments per unit of warehouse capacity and cargo capacity of vehicles;
- input-output ratio for reflecting the dynamics of output and workflow;

- the ratio of operational logistics costs per unit of invested capital;

- the ratio of logistics costs per unit of output;

- logistics costs in distribution per unit of sales volume, etc.

The complex indicator - return on investments in the logistics infrastructure - characterizes the efficiency of investments in the logistics infrastructure units, which are currently classified as:

- warehouse (warehouses of different types and purposes, cargo terminals and terminal complexes);

- transport units of various types of transport;

- transport communications (roads and railways, railway access roads, etc.);

- repair and support branches serving the transport and storage facilities;

- telecommunication system;

- information and computer system (complex of technical means and office equipment).

Return on investment in the listed objects of the logistics infrastructure is determined in accordance with the current regulatory and methodological documents to assess the effectiveness of investment [14].

The system of indicators should be based on the content and purpose of the infrastructure and meet the following requirements:

- reflect some aspects and effectiveness;

- to ensure the comparability of analytical indicators;

- most accurately measure the relevant phenomena and process parameters;

- give quoted (graphically displayed) results.

The problem of choosing representative indicators of the effectiveness of the infrastructure and its forms is to develop an integral indicator that allows us to compare the levels of infrastructure efficiency in different countries.

The solution experience shows the possibility of active use of scoring system, calculation of structural indices, mathematical statistics formulas, in particular, calculation of deviations of the actual state of infrastructure development from the norm or other indicator. On the basis of the calculated indicators, it is possible to perform a so-called mapping of results that allows the use of the chart sign "graphical method of visual assessment of complexity, where the value of each of the indicators is expressed by the length of the vector. Technical and economic-mathematical methods allow you to compare the effectiveness of the infrastructure potential at different territorial levels and represent a convenient tool for applying analysis of infrastructure support for railway transport [20].

Nowadays there are few scientific approaches that take into account the many factors that influence the increase of the efficiency of the railway infrastructure. At the present stage, computer support allows to use for the evaluation of the effectiveness of infrastructure support for rail transport previously inaccessible due to the large 
Table 1 Initial data for factor analysis (mean value of indicators (1997-2016))

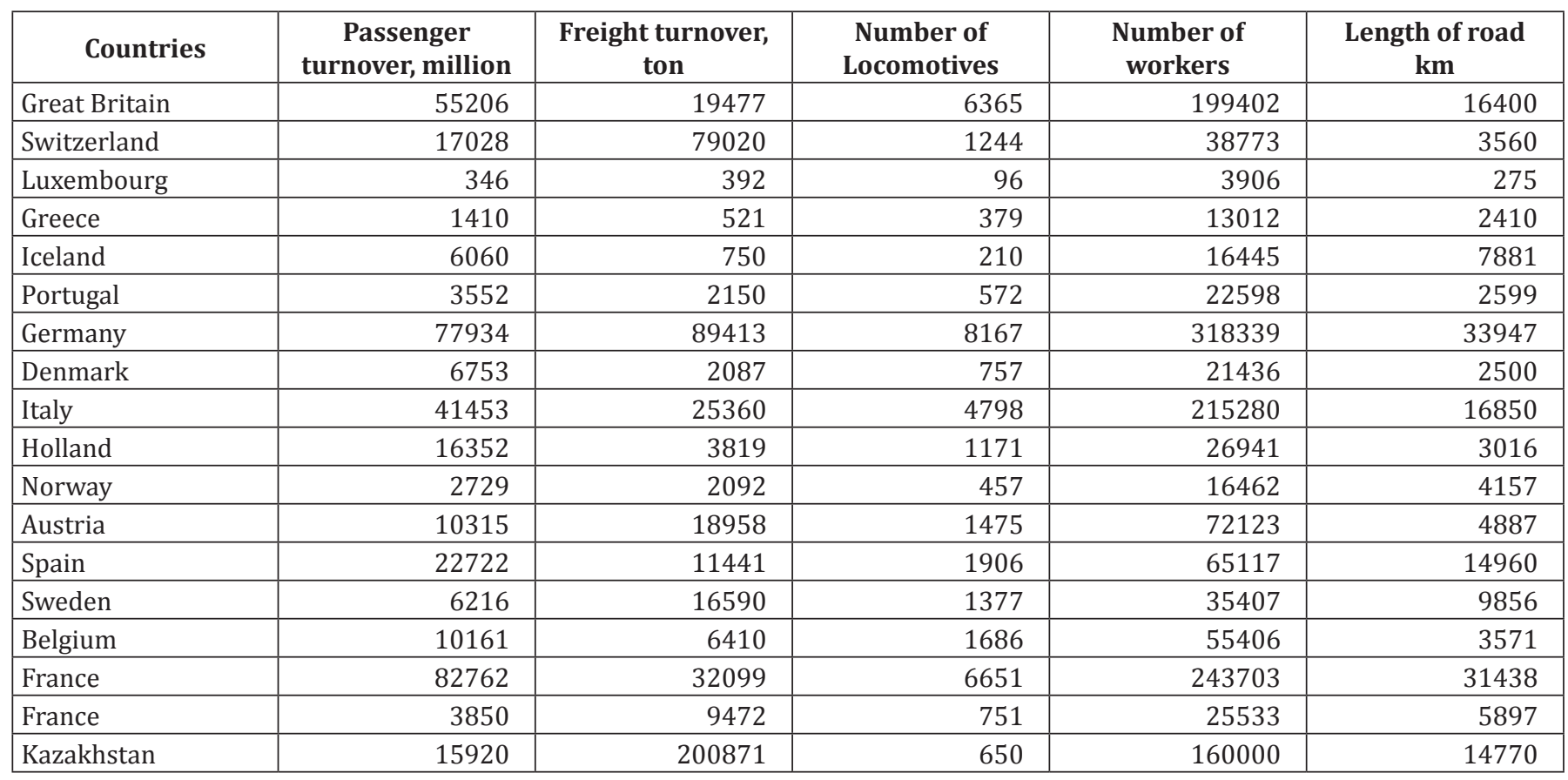

Source: UIC data available on the Internet [32]

Table 2 Correlation analysis of the dependence between the values (average 1997-2016)

\begin{tabular}{|c|c|c|c|c|c|c|}
\hline Countries & $\begin{array}{c}\text { Passenger } \\
\text { turnover, million }\end{array}$ & $\begin{array}{c}\text { Freight } \\
\text { turnover, ton }\end{array}$ & $\begin{array}{c}\text { Number of } \\
\text { Locomotives }\end{array}$ & $\begin{array}{c}\text { Number of } \\
\text { workers }\end{array}$ & $\begin{array}{c}\text { Length of road } \\
\text { km }\end{array}$ & $\begin{array}{c}\text { GDP } \\
\text { \$ million }\end{array}$ \\
\hline Great Britain & 55206 & 19477 & 6365 & 199402 & 16400 & 2,7 \\
\hline Switzerland & 17028 & 79020 & 1244 & 38773 & 3560 & 0,68 \\
\hline Luxembourg & 346 & 392 & 96 & 3906 & 275 & 0,04 \\
\hline Greece & 1410 & 521 & 379 & 13012 & 2410 & 0,2 \\
\hline Iceland & 6060 & 750 & 210 & 16445 & 7881 & 0,25 \\
\hline Germany & 77934 & 89413 & 8167 & 318339 & 33947 & 3,6 \\
\hline Denmark & 6753 & 2087 & 757 & 21436 & 2500 & 0,32 \\
\hline Italy & 41453 & 25360 & 4798 & 215280 & 16850 & 1,9 \\
\hline Holland & 16352 & 3819 & 1171 & 26941 & 3016 & 2,1 \\
\hline Norway & 2729 & 2092 & 457 & 16462 & 4157 & 0,43 \\
\hline Belgium & 10161 & 6410 & 1686 & 55406 & 3571 & 0,47 \\
\hline France & 82762 & 32099 & 6651 & 243703 & 31438 & 2,6 \\
\hline France & 3850 & 9472 & 751 & 25533 & 5897 & 0,24 \\
\hline Kazakhstan & 15920 & 200871 & 650 & 160000 & 14770 & 0,15 \\
\hline Value & 0,40011 & 0,77122 & 0,926057 & 0,824709 & 0,821891 & \\
\hline
\end{tabular}

Source: Calculated and compiled by the authors

number of calculations of the methodology, based on the application of economic and statistical modeling.

The operation of calculating the influence of different groups of factors on the efficiency of the railway infrastructure can be carried out using technical and economic, economic and mathematical calculations, as well as multifactorial integral estimates. The connecting link between the heterogeneous parameters under consideration can be the method of multidimensional factor correlation analysis, which is based on the apparatus of mathematical statistics.

Corinne Blanquart \& Martin Koning (2017) The analysis of the efficiency of the railway infrastructure was carried out based on the data of 16 countries of the world 
with the most developed infrastructure, majority of which are European countries [21]. Based on the calculation of the correlation coefficients for the surveyed objects, factors that significantly influenced the value of the gross domestic product were selected (Table 1).

Table 1 shows the initial data for the factor analysis. We reviewed the indicators of all quantitative data on rail transport. A multifactorial mathematical model is compiled in the study. For the function (y) studied, the gross domestic product of each country and the main indicators of the efficiency of infrastructure provision of rail transport are taken.

In Kazakhstan, we can observe a recovery in the overall economic situation, an increase in the number of vehicles from businesses and the population, which entails a sharp increase in the volume of passenger and cargo transportation. However, the current state of the transport infrastructure is not able to satisfy the consumers of transport services.

\section{Research Results}

In the studies of R. Alchanova (2009) 5 factors influencing the development of infra-structure are shown. Based on this model, the following factors affecting the efficiency of infrastructure provision of railway transport are analyzed: X1 - passenger turnover (number of people), million people; X2 - freight turnover (million tons); X3 - number of locomotives; X4 - number of employees employed in the railway transport infrastructure, people; X5 - length of roads, $\mathrm{km}$. Leibenstein H (1996) uses the term X-efficiency in its studies [17]. Based on the data in the table, we calculated the correlation between the values (Table 2).

Oveshnikova L.V. (2013) analyzes and ranks the factors of infrastructure development, and we obtain and analyze the results of a multicriteria and multifactor evaluation of the efficiency of the railway infrastructure using the correlation analysis method to give us the following conclusions [9]. Based on the data obtained, it can be concluded that the effectiveness of infrastructure depends more on factors X3, X4, X5, which corresponds to technical changes in the infrastructure of railway companies.

\section{Discussion}

Thus, based on the compiled multivariate mathematical model, factors that exert the greatest importance on the resulting feature - the efficiency of infrastructure provision of railway transport can be determined. The obtained results give grounds for forming a spectrum of various managerial actions and decisions in the sphere of railway infrastructure development.

The analysis of productivity in the railway sector was primarily focused on studying the efficiency of railway companies of different countries and its determinant, thus lowering the contribution of technical changes. The only study that analyzes performance growth with technical changes (Gathonand Pestieau, 1995) does this on the basis of the parametric boundary approach, which requires both a specification of the functional form for the data, and the imposition of a special distribution function

Table 3 International lines of high-speed trains for 2016

\begin{tabular}{|c|c|c|c|c|}
\hline Country & $\begin{array}{c}\text { In operation } \\
\text { km }\end{array}$ & $\begin{array}{c}\text { Under construction } \\
(\mathrm{km})\end{array}$ & $\begin{array}{c}\text { In the planning stage } \\
(\mathbf{k m})\end{array}$ & $\begin{array}{c}\text { Current place in the } \\
\text { rating }\end{array}$ \\
\hline Belgium & 209 & - & - & 12 \\
\hline Germany & 1475 & 368 & 324 & 5 \\
\hline Italy & 923 & 125 & 221 & 6 \\
\hline Spain & 2871 & 1262 & 1327 & 3 \\
\hline Switzerland & 87 & 72 & - & 15 \\
\hline Great Britain & 113 & - & 543 & 14 \\
\hline China & 21,688 & 10,201 & 677 & 1 \\
\hline The USA & 362 & 483 & 1023 & 9 \\
\hline Kazakhstan & 15,038 & & 2 & 17 \\
\hline Total & 34,679 & 14,559 & 8390 & \\
\hline
\end{tabular}

Source: Data from the International Union of Railways available on the Internet. These statistics only include countries that already have High-speed rail lines in service [33] 
for the error [19]. In this case, it was also necessary to combine the results, which prevents the capture of the effect of specialization. In this context, the aim of our study was to analyze the recent evolution of productivity on the railways, destroying its growth to changes in efficiency and technical changes.

Fare R, Grifell-Tatjé E, Grosskopf S \& Lovellcak (1997) considered that the most important efficiency factor is technical changes[16]. The results of our study show that the greatest increase in productivity was due to improvements in technology, and not due to more effective behavior of companies, especially in the period of 1997-2016.

Only Britain and Italy showed an increase in efficiency during this period. In this sense, countries such as Holland, France, Germany and Norway have markedly increased the indices of technological progress, which explains the significant increase in their level of productivity. Our results shown in Table 3 also allow us to explain the performance indicators of railways, as well as the evolution of their rates of technical changes and the increase in the number of high-speed trains. The degree of autonomy and professionalism in management appears to be a key element in explaining the level of efficiency of companies and the degree their technological evolution.

On the railways of Norway, the growth of the volume of freight traffic is growing at a fast pace, and all the operator companies note the need for the modernization of the mainlines, where reserves are almost exhausted. Therefore, a plan is adopted for doubling the network throughput over the next decade. In addition, to improve the quality of passenger traffic, it is expedient to consider the issue of creating a system of high-speed messages.

Throughout the period, many of the companies underwent major restructuring processes, the main purpose of which was to improve the level of productivity with which they worked. Therefore, a strong increase in productivity over this period seems to reflect the effectiveness of these measures. For example, after determining the amount of funding for long-term projects in accordance with the "Strategic Plan for the Development of Transport and Transport Infrastructure for 2005-2020", the Government of Spain, the National Railways of the country and the administration of the railway infrastructure have begun considering investment projects for the medium term.

Färe R, Grosskopf S, Morris M \& Zhang Z (1994) and Preston J.M \& Nash C.A (1996) in their research have determined that the economic growth of each country is due to technological progress and effective changes [16] [20]. Spain has the highest rates of construction of railways in Europe. First of all, attention is paid to expanding the network of high-speed lines. In 2005, the railways of Finland met the record volume of passenger traffic, and their growth continued in 2006. Opening the traffic on the newly built Kerava-Lahti line and the new traffic schedule will improve the level of service in passenger traffic. In freight transport, it is likely that they will face competition, which will become possible thanks to free access to the infrastructure and other operators.
In the early 2000s, the Swedish railways were on the verge of bankruptcy, caused by unfavorable contracts and the chronic ineffectiveness of operational activities. The modern policy of the operator StatensJärnvägar is aimed at restoring positions in the market of passenger traffic and returning to profitability due to the renewal of rolling stock and the modernization of the infrastructure.

Explaining the more productive behavior of companies with less state control is that companies with greater freedom to choose their prices, quality of service, etc., have more incentives for freedom and participate in investment processes that are directed technological progress. Our results also show that the most financially solvent companies are the most technologically innovative. This can be explained by the fact that these companies are less dependent on government subsidies, and therefore have more incentives to implement the investment and innovation program.

Several factors influence the situation with the maintenance and repair of the rolling stock of the Federal Railways of Switzerland: all the fierce competition, growing price pressure, excess production capacity on a pan-European scale, the intensification of rolling stock operation, manifested with each change of schedule, shortening the duration of idle time, and so on. Against this background, there is an increasing desire to make better use of available resources and increase productivity.

Isaev A.G. (2014) in his studies considered from the point of view of public investment in infrastructure as the determinants of economic growth, supporting his ides we came to the conclusion that developed companies with a higher degree of autonomy are those that clearly experience the highest technological development[12]. Competition with other modes of transport and the struggle to attract new passengers are some of the factors that explain the expansion of the scale of modernization of rolling stock of railways. Editorial Civitas Vickers J \& Yarrow G (1988) in their articles on the basis of economic analysis determined the role of privatization. Many passengers perceive the modernized rolling stock as new. Only a small part of the German railways is completely private. However, almost all of them are organized in the model of private companies to achieve higher efficiency and flexibility, allowing dynamically to respond to market demands. In this case, not only the interiors of wagons are updated. Constructive improvements in the mechanical or electrical parts of trains, the replacement of obsolete and worn out assemblies contribute to increased reliability and lower operating costs.

PCC Intermodal plans to build a network of open terminals for intermodal communications in Poland. This project can initiate strategic investments in the containerization of transportations in the scale not only of a single country, but also of Central and Eastern Europe as a whole.

The railways in the United States, due to geographical and economic reasons, developed differently than in Europe. In this regard, a number of technical features have infrastructure, rolling stock, the nature of the operation, as 
well as the process of economic development of the railway sector enterprises.

In recent years, the railways of the Republic of Korea have made significant progress in strengthening the financial situation and increasing the attractiveness for users. The national operator Korail (the company is wholly owned by the state) has significantly improved the financial performance of the operation, while the administration of the railway infrastructure Korail is implementing a large-scale investment program aimed at the development of the railway network.

\section{The Great Silk Road}

China's railways are experiencing a period of rapid recovery, expansion of the network, improvement of quantitative and qualitative indicators of operational activities, development of high-speed passenger and heavy cargo transportation. The development of railways is carried out on the basis of long-term perspective plans. In addition, the country's industrial base for the production of rolling stock is being strengthened, and advanced foreign technologies are being borrowed. This creates the prerequisites for further growth.

Many scholars of Russia, Kazakhstan and China are discussing the revival of the Great Silk Road. Now there is a need to deepen research, because the Great Silk Road is the road that unites the whole world. The Great Silk Road as a trade highway originated in the III century $\mathrm{BC}$ and existed until the 16th century. It was a system of caravan roads leading from China to the countries of the Middle East and Europe. A significant part of this route ran through Central Asia in Central Asia and Kazakhstan. The countries included in this node, in addition to the
Central Asian states proper, occupy a significant part of the globe. This, on the one hand, the EU member states, Africa and Japan, on the other - Russia, China and Iran. China announced a strategic concept for the creation of the "economic belt of the Silk Road." It is a question of a new direction of economic development of the regions located along the historical route of the Great Silk Road. The new route will run through the continent of Eurasia, crossing many countries. It will affect 3 billion people, and will also connect the Asian, Pacific and Western European economic circles. The project "Economic belt of the Silk Road" differs from this model. Its main goal is cooperation in trade, transport and investment. The strategic concept of the "Economic belt of the Silk Road" consists of five points: political ties, the combination of roads, free trade, monetary circulation and the common aspirations of peoples [22].

Connection of roads implies improvement of crossborder infrastructure, construction of a transport highway between China and Europe, improvement of conditions for economic development and movement of people [23].

According to the estimates of leading scientists and experts in the field of transport, it is the Central Asian region that will be the most important transport site in the next 20-25 years, providing the connections between Western China and Western Europe. The economic benefits of the project will be provided to all participating countries [24].

China pursues a policy of diversifying transport corridors. Now there are three ways from China to Europe:

1. Trans-Siberian railway - $13000 \mathrm{~km}$ - from the border with Russia to Rotterdam;

2. The route Shanghai - Rotterdam $-15000 \mathrm{~km}$.

3. Sea way from the port of Lianyunchan to Rotterdam $10900 \mathrm{~km}$.

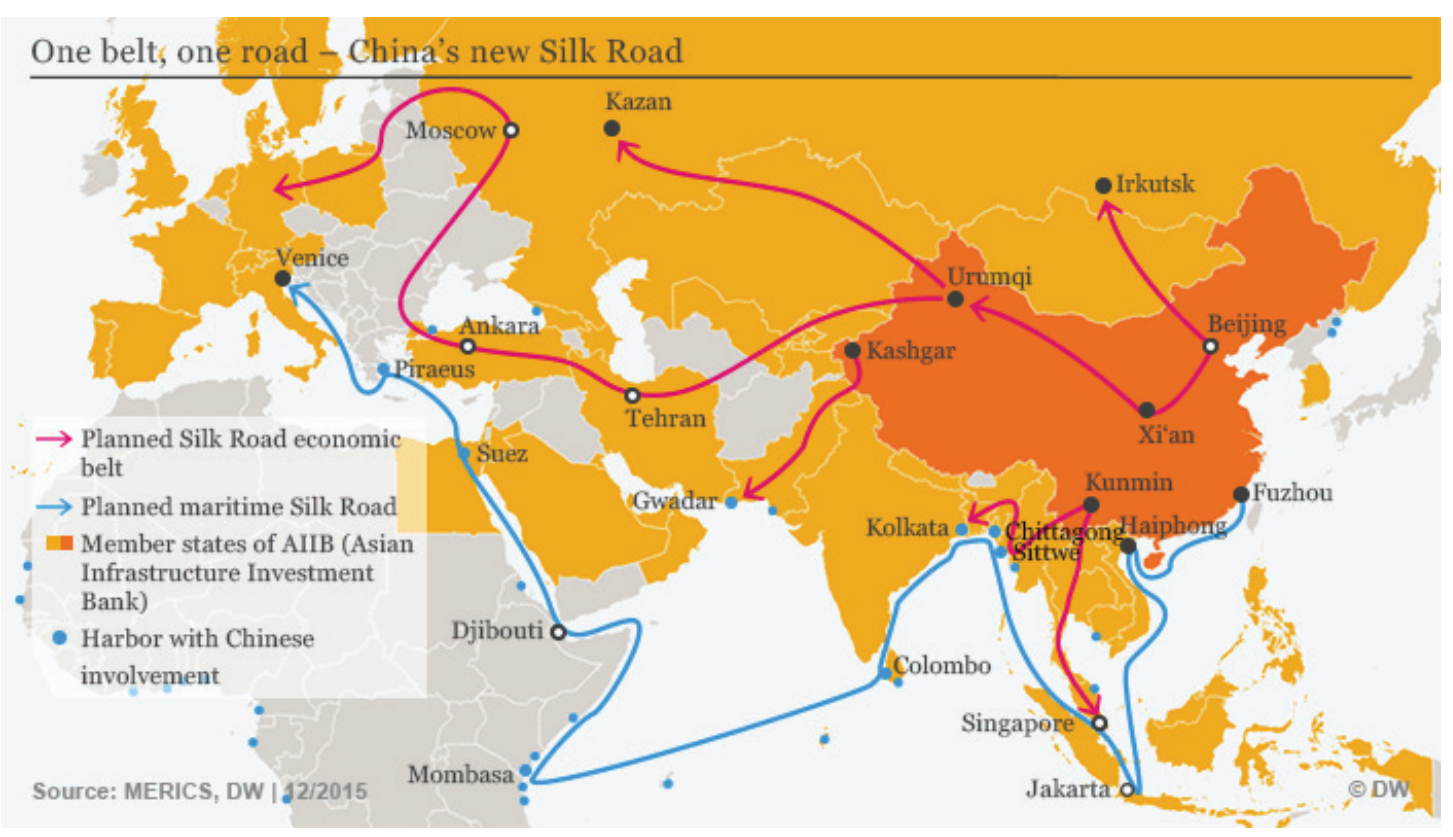

Figure 1 One belt, one expensive, the "Silk Road" [30] 
The strength and potential of the New Silk Road is in its universality. This new network of updated transport routes and new trade hubs will be laid between China and Europe. Efficiency, safety and healthy competition is that this is not one route, but a whole network of many interconnected trans-Eurasian corridors. Eurasia, the continental massif that unites Europe and Asia, is rapidly being drawn into a single market, covering over $65 \%$ of the population, $75 \%$ of energy resources and $40 \%$ of GDP in the world, and it is the revolutionary railway routes that link all this together. Optimal is a closed loop, in which the containers transport goods in both directions. The side of China-Europe has now intensified - almost two thousand trains are now crossing Eurasia in a western direction. Now it is necessary to fill the trains that return from China. This gives Europe a new opportunity to gain access to the rapidly evolving Chinese middle class. The strength of China's "One Belt, One Way" and the wider New Silk Road is to create a diverse and interconnected network - a strengthened economic system throughout Eurasia. In this network there will be no single route, the work of which would be easy to break. "Secondly, our approach to infrastructure development must be fundamentally new. Infrastructure should expand the opportunities for economic growth. Development of infrastructure is necessary in two directions: to integrate the national economy into the global environment, and also to move to the regions within the country." To create joint ventures in the region and all over the world - Europe, Asia, America, such as, for example, ports in countries with direct access to the sea, transport and logistics hubs in key transit points of the world and so on [25].

The "Silk Road" project involves 29 heads of state and government, the first leaders of the United Nations, the
World Bank, and the International Monetary Fund. In general, the geography of the participants covers about 130 countries around the world. The initiative promoted by the PRC implies the construction of overland roads and sea routes linking states, regions and continents, creating zones for economic cooperation, strengthening trade ties and cooperation. An important role is given to innovation - the participating countries of the initiative should take the path of innovative development, intensify cooperation in the advanced fields (digital economy, artificial intelligence, nanotechnology, quantum computers, "big data", "smart cities") and build "the digital Silk Road XXI century". According to some estimates, it will take about 30 years to implement it. However, the strategy is already becoming a reality: the Asian Bank for Infrastructure Investments (ABIA) and the Silk Road Fund have been established in China. The project offers attractive prospects: to maximize the use of large-scale transit potential, to modernize transport and logistics infrastructure [26].

\section{The Role of Rail Transport and Maritime Transport in the Development of the Silk Route}

The modern Great Silk Road is a gigantic economic force, truly capable of changing the world market. Moreover, there are a lot of options for the "New Silk Road", and not all of them run through Siberia. There is, for example, such a route: China - Kazakhstan - European part of Russia - Belarus - Poland - Germany. Further by sea: Portugal - Egypt - India - Singapore - China. But there is also a variant of the northern branch of the route - along the Trans-Siberian Railway.

Transit corridors from Western China to Europe as a whole are divided into three groups: the Northern Route

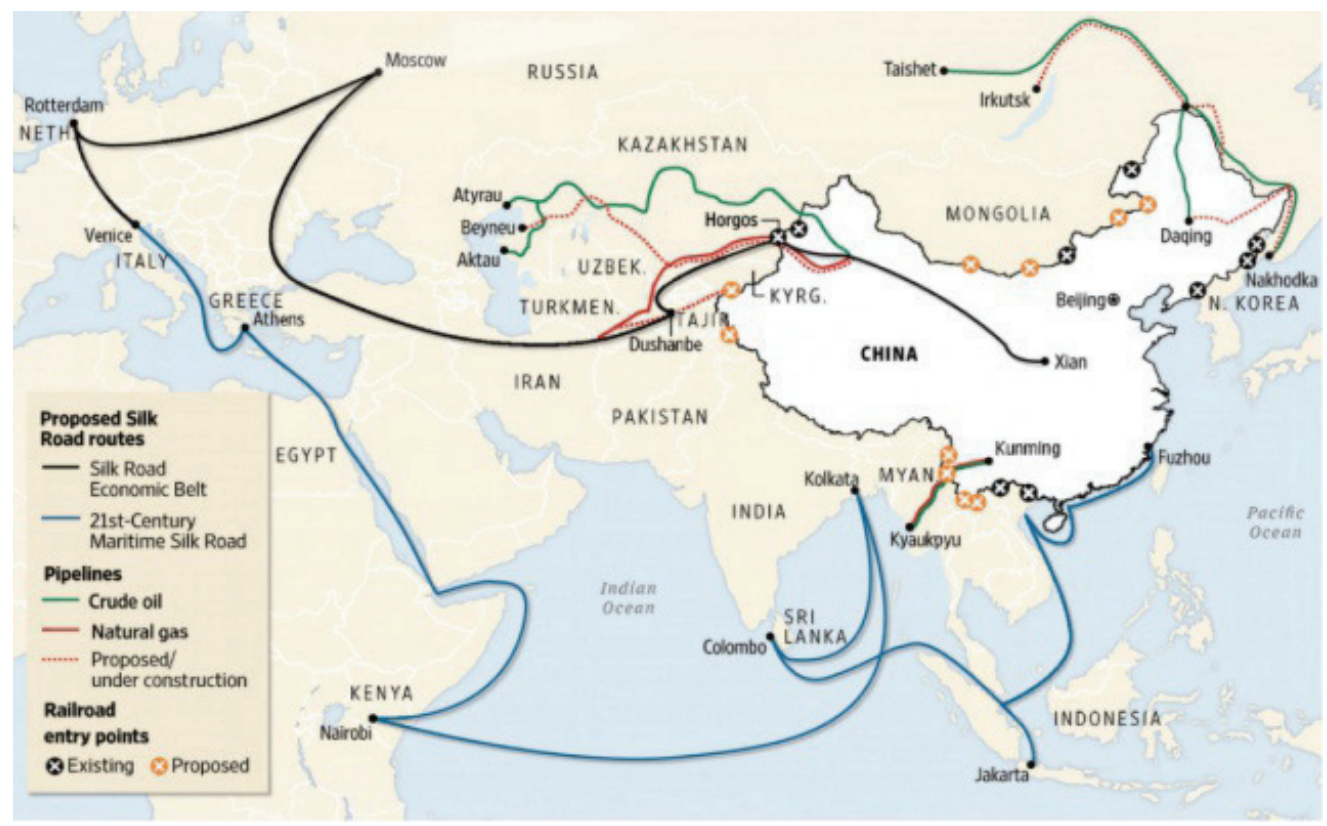

Figure 2 Khorgos - Eastern Gate [31] 
(it is recognized as the most promising and prepared route), the Sea Route and the Southern Route. The northern route goes through Kazakhstan and Russia (along the Trans-Siberian Railway). The sea route includes routes passing through the territory of Kazakhstan and using the ports of the Caspian Sea for transit to Turkey. The southern option is a way to bypass Russia through Kyrgyzstan, Uzbekistan, Turkmenistan, Iran and Pakistan with access to the Indian Ocean in the Persian Gulf region. China is also working on a new route - the high-speed Asia-Europe highway and several projects under the "continental bridges program". They will connect China with Eurasia, Eastern Europe and the Mediterranean. You can consider these undertakings as an attempt to revive the historical Silk Road in the new edition. Indirectly in the development of the "New Silk Road", India is also interested [27].

There is a whole set of alternatives competing with each other for transport routes: along the Northern Sea Route, through the Suez Canal, various automobile routes and railroad tracks.

The land section of the economic belt of the Silk Road consists of three railway corridors (northern, central and southern), which can be used to lay the necessary ways for road and other transport. The northern route of the railway route extends from Western China to Europe through Kazakhstan and Russia to the Baltic Sea, from where a branch will pass through Belarus and Poland to Germany and Holland. The central railway corridor will provide transit from the ports of Central China (Shanghai, Lianyungang) through the countries of Central Asia (Kyrgyzstan, Uzbekistan, Turkmenistan), Iran, Turkey, the Balkan Peninsula to the ports of France. This route is considered as the most difficult to implement, given the political situation along it, the lack of an appropriate infrastructure. For its launch, it is also necessary to build an additional tunnel under the Bosporus strait, since the existing tunnel is overloaded. The southern route will take two branches: from China to Pakistan, on the one hand, and from China to India, Bangladesh and Myanmar, on the other.

Containers use routes that go through China, through Kazakhstan. About 1.5 thousand kilometers of new roads were built, the port of Kuryk is already working. Kazakhstan is actively interested in Georgia as a transit country. Kazakhstan leased Batumi port for 49 years. And of course, the guarantor of the success of the project "One Belt is One Way" is the newly opened Baku-Tbilisi-Kars railway. One of the branches of the "New Silk Road" that connects Asia, Europe and Africa. "The new railway will connect the Baku port of Alat, Tbilisi and the Turkish city of Kars, the length of the route is 826 kilometers." It will be possible to get from London to Beijing in just 15 days. This is three times faster than the sea, and will cost more than two times cheaper than an airplane. The Silk Road through China, Kazakhstan, Uzbekistan, Russia, Georgia, Turkey, Greece, Italy. The ultimate goal will be the capital of Italy Rome. On the road, it is planned to spend at least 56 days and cover a distance of 15,000 km (30,000 liters) [28].
On the way, a new path of cooperation is the deep-sea port of Anaklia. The road to Western Europe - Western China is planned to be extended to the Lanyungang sea port. In China, 584 train trains passed through Kazakhstan to European countries. In total, these trains departed from 17 cities in China. They choose such a route not in vain, because it is much cheaper than air transportation and much faster than shipping. By sea, goods from China go to Europe for a month and a half, whereas on this branch of the Silk Road through Kazakhstan the journey takes two weeks or 10 days. Cargo transportation from China to the UK, France, Germany and other European countries along the Southern and Northern Corridor, including the sea route, takes 45-62 days. Completion of the construction of the highway to Turkish Kars means that now the way from China to Europe will really become more convenient, because there is no need to transship goods across the Black Sea. The railway communication has already been established from Kars to the border with Europe (through Greece and Bulgaria). But cargo from China to Baku will be delivered through the Caspian Sea, by ferry. The railway corridor through Pakistan and further through Iran is of great importance. That is, in this project there is a combination of two projects of the strategy "One belt - One way" - the Sea Route and the Economic belt. Russia "is taking measures to use its unique geographical location to increase transit cargo traffic for the purpose of optimal development of trade and economic ties between Europe and the Asia-Pacific region. In the future, the strategic plan for the construction of the Economic belt of the Silk Road and the Silk Road of the 21st century will be implemented."

Almost all rail transportation from China to Europe is unprofitable, but their freight turnover continues to increase, with a constant decline and tariffs. The Chinese authorities continue to generously finance overland routes to Europe in various regions of China.

Kazakhstan is the largest country in the world, which has no access to the sea. But the favorable geographical location on the path of the growing trade flow between Europe and Asia gives us a number of advantages. The main role in it is played by rail transport. The length of railways in the republic exceeds 15 thousand km. 16 border points ( 11 with Russia, 2 with Uzbekistan, 1 with Kyrgyzstan, 2 with China) connect the railway system of Kazakhstan with neighboring states. The Russian and Kazakh railway systems are highly interdependent.

On the development and promotion of multimodal transport corridors that will allow the transit of goods through the territory of Kazakhstan in the following directions from China: to the Russian Federation and further to Europe; from Khorgos to the port of Aktau, then along the Caspian Sea to Azerbaijan, and then through Georgia, Turkey and further to Europe; to Iran, the Middle East, India and Pakistan; in the direction of North-South through the territories of Russia, Kazakhstan, Turkmenistan and the countries of the Persian Gulf.

All freight flows from China to the countries of Europe and Central Asia are consolidated in the FEZ "Khorgos 


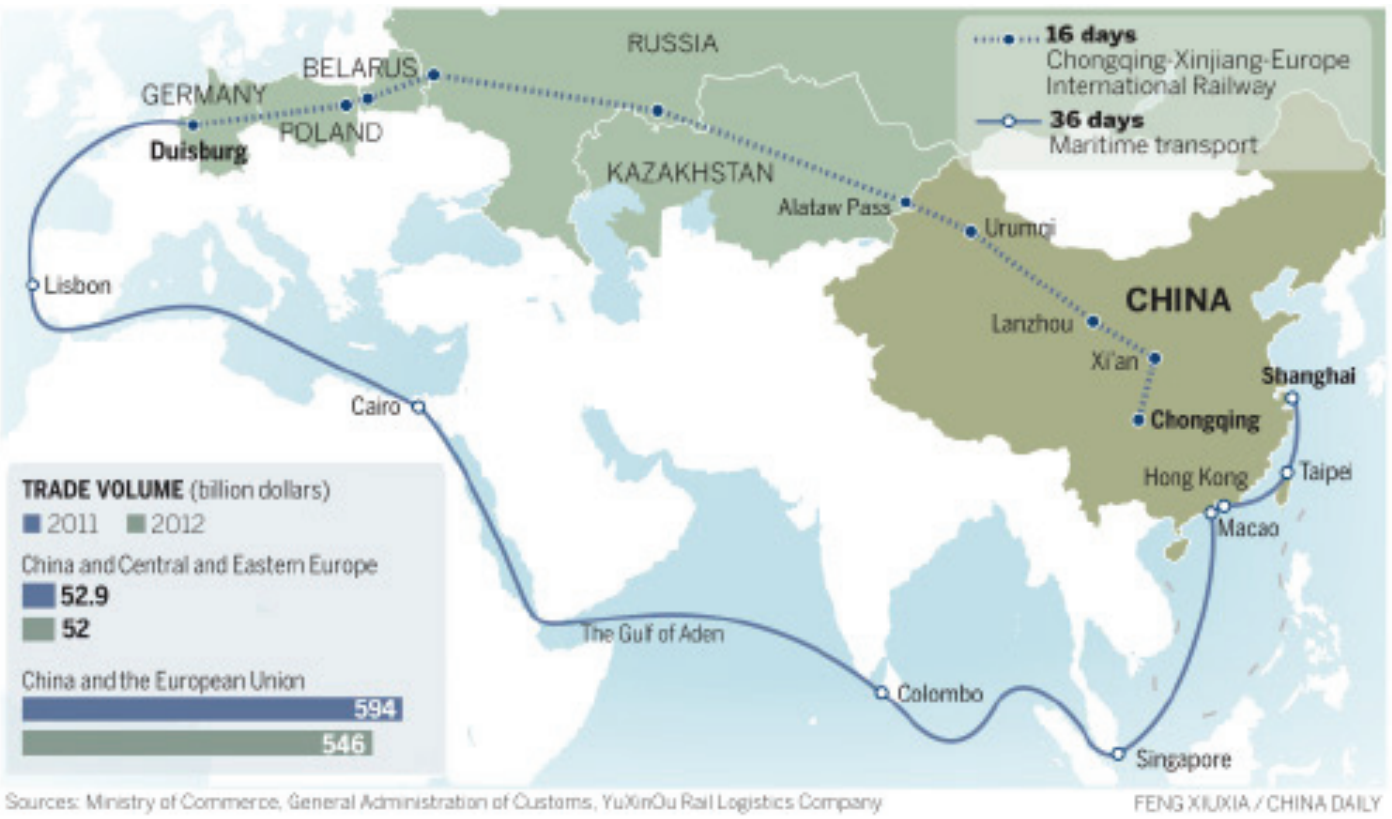

Figure 3 Khorgos - Eastern Gate [31]

- Eastern Gate" on the eastern border with China. In its significance the gates fulfill a strategic role similar to the Suez Canal.

There is water transport in the steppe Kazakhstan. Through the Caspian Sea the country is connected with Russia, Iran, Azerbaijan, Turkmenistan, and through the rivers and the channel network of Russia - with the Black and Baltic Seas, and further with the states of Europe. Western ports of the transport and logistics system of Kazakhstan and simultaneously the strategic junction of the Eurasian multimodal transport corridor are the ports of Aktau and Kuryk in the Caspian. The Caspian plays a strategic role in the implementation of the transit potential of the region and the intensification of multimodal transport, being the maritime link of the transcontinental transport corridors "East-West". "The Trans-Caspian route from China to the Caucasus, Turkey and Europe, the route from China to the Persian Gulf through Kazakhstan and Turkmenistan, and the North-South corridor passing through Russia, Kazakhstan, Turkmenistan and Iran are developing to fully realize the transit potential of Kazakhstan."

Within the framework of the One-Belt and One-Way Initiative, China is developing several new land and sea routes. These projects do not compete with the transport corridor, and some of them even contribute to its development. In recent years, the railway has become an attractive alternative to sea and air transport for freight traffic between Germany and China. This project is promoted as an alternative to maritime transport[29].

The delivery time by rail (16-20 days) is much less than by sea transport (up to 45 days). The cost of sea transportation is lower, however, compared to air transport, rail transportation is more profitable. Thus, it is expedient to transport valuable goods by rail (for example, vehicles and electronics), as well as promotional goods (for example, textiles and seasonal products), which need to be delivered quickly and at the same time as cheaply as possible.

The cargo follows the route from Chinese Urumqi by rail through Kazakhstani Dostyk to the port of Aktau, from there - by ferry across the Caspian Sea to the Azerbaijani port of Alyat, then by rail through Azerbaijan to Batumi, from where it is delivered by ferry to Istanbul. The route was named "Silk Wind" and was developed at the end of 2012 within the framework of another TRACECA transport and logistics project (transport corridor EuropeCaucasus-Asia) aimed at strengthening international economic cooperation between the European Union and the countries of the Black Sea region, the South Caucasus and Central Asia.

1. The Trans-Asian-Caucasian route can reduce travel time by several times compared to sea transport, which are still leaders in the ways of delivering goods from China to Europe. If the cargo goes to Europe 40-45 days by sea, then the route "Silk wind" time is reduced by four times. The launch of this railway line will avoid the second ferry crossing from Batumi to Turkey via the Black Sea. Multiple (more than four) change of modalities is the main problem of the new route from China to Europe through Georgia and Turkey. Transshipment of containers in four ports inevitably leads to a significant rise in the cost of transportation. In addition, it requires the appropriate infrastructure solutions - the purchase of expensive capacious ferries (while in the Caspian Sea on the route from Aktau to Alat, flights are made twice a week, and daily ferries are required to fully load the Silk Wind and compete with the Transsib).

Having redirected some existing routes, it complicates the situation for those who are satisfied with the state of 
things, and this will affect the life of seaports. The intensity of traffic in the Suez Canal has fallen, as fuel prices have fallen, and many ships follow a longer path, skirting the Cape of Good Hope "New Silk Road" through Kazakhstan and Russia (16 days) in comparison with the way through the Suez Canal (36 days). While the main competitor of Transsib is not railroads bypassing Russia, but sea routes, in particular the sea route from Shanghai to Hamburg (Germany). It is they who dominate the cargo transportation market between Asia and Europe. There are several reasons for this: the shipping by the sea is cheaper (about $\$ 3$ thousand against $\$ 8$ by rail), bigger (the container carrier can take on board about 17,8 thousand TEU). The minus of sea transportation is the duration of the route: on average, cargo from China to Europe by sea goes around 40-45 days, whereas by rail they can be delivered within 7-10 days. The development of the Trans-Caspian international transport route that runs through Kazakhstan, then the Aktau port, "floats" to Baku, then by the Baku-TbilisiKars railway to Turkey, or Europe [30].

2. Rail Rail Railroad in Conditions of Increase in Sea Transport Cost would be for Finns one of the alternative possibilities.

The Baltic Sea now takes a general trend towards a cleaner environment, which has led to a situation where sea transport is significantly more expensive.

3. The Israeli project the creation of a new seaport in the future will provide a railway connection between Eilat and the seaport and will constitute a land alternative to the Suez Canal. The port will communicate with other ports of the Mediterranean Sea, as well as with the network of Israeli railways.

While "switching" customers from sea transport to rail container transport is very difficult. The railway has its own difficulties: it is a non-guaranteed delivery time, delays, complicated customs procedures. If customs procedures related to the distribution of goods take place in St. Petersburg (Russia), the client usually chooses the transportation by sea. The Finnish ports, like their neighbors on the Baltic Sea - Estonian, Latvian and Lithuanian sea harbors, intend to join the fight for the Chinese transit. In particular, the Finnish port of Hamina-Kotka is interested in the project "New Silk Road". China will use St. Petersburg in its route, and some of the cargo will be delivered to the Finnish port. In Khamin Kotka they hope for cooperation with St. Petersburg ports, notes Manninen. At the same time, Kazakhstan's national logistics operator KTZ Express is now developing cooperation with the Lithuanian port of Klaipeda. Russia needs to promote the idea of a "northern" branch of the "New Silk Road" to the Russian ports of the Gulf of Finland. In order not to be on the periphery of the infrastructure mega-project put forward by China, the Northwest should provide local ports as an alternative route for Chinese cargo.

Finnish carriers and ports intend to use the opportunities of the Chinese project "New Silk Road" with maximum benefit. The "New Silk Road" is a land corridor connecting China with European markets. The terms of delivery of goods by rail from Central China to Europe are about two weeks, which is $2.5-3$ times faster than by sea around the whole continent through the Suez Canal.

The sea part of the Silk Road goes through Guangdong and the southernmost province, Hainan Island, then through the Indian Ocean. He crosses the African horn and heads to the Red and Mediterranean seas. Both ways are found in Venice. The main direction of the "New Silk Road" through Central Asia is supposed to be about 6,500 kilometers long, of which 4,000 will pass through the Chinese territory from the Pacific coast to the Xinjiang Uyghur Autonomous Region. Then the way goes through Kazakhstan, Uzbekistan, Turkmenistan, Iran, Iraq, Syria and Turkey, and from there to Europe - through Bulgaria, Romania and the Czech Republic to Germany. Also, offshoots from the main route are also planned for many other neighboring countries.

The sea route, as well as the land route, will pass along the ancient trade route: from Guangzhou to China along the coasts of Vietnam, Thailand, Malaysia, Singapore and Indonesia, past India to the Red Sea with branches to the Persian Gulf and Africa, and through the Suez Canal in the Mediterranean. As a separate entry point to Europe before the Ukrainian crisis, the Chinese planned to build a deep-water port in the western part of the Crimea. In addition, Russia and China are also discussing the Arctic route: the possible inclusion of the Northern Sea Route (NSR) development project in the strategy of the New Silk Road [25].

The American project of the "New Silk Road" was considered by its creators as an alternative to the Eurasian Economic Union. Its essence was the trade and economic integration of the countries of Central Asia, Afghanistan, Pakistan and India, as well as the expulsion of Chinese and Russian companies from this huge market. As part of the American New Silk Road, the construction of the Hayraton-Mazar-i-Sharif railway line in Afghanistan and small objects - roads, bridges. Large projects, such as the construction of a high-voltage CASA-1000 line that could provide Afghanistan and Pakistan with electricity from Tajikistan and Kyrgyzstan, or the TAPI gas pipeline (Turkmenistan-Afghanistan-Pakistan-India) are no more than ideas that are unlikely to be are implemented. 2017 that the initiative is gradually shifting from maritime superpowers to continental ones. In addition, the United States near future to connect to the Chinese initiative "One belt - one way." Today, China and the United States transport 40 million containers a year. When the "Silk Road" is completed, at least 10 percent of this volume will pass through Russia - 4 million containers.

It is known that most of the cargo from China to Europe, including Russia, is transported by sea. At the same time carriers in the struggle for leadership are constantly increasing the tonnage, regularly placing orders for the construction of new vessels.

The basis for the implementation of the world project "Silk Road" is the 5C principle - speed, service, cost, safety and stability [28]. 
We need to offer competitive conditions for the carriage of goods by all types of transport: sea, rail, road, air. It is attractive, profitable and safe for passengers, shippers and consignees. And much depends on the authorities' desire to build multimodal transportation, when the cargo goes by sea, then by rail, and the delivery to the doors is already being conducted by car. It is important to develop regional aviation, as well as shipping routes, to transport more cargo not by road but by rivers. So on the road the load will be less, which means that they will last longer, and the transportation itself will be cheaper.

There are more than forty countries in the world that do not have direct access to sea transport, thus being cut off from the cheapest transport route. And their trade relations largely depend on the level of development, transit opportunities and openness of neighboring countries. "Railway transport is the most optimal. Avia - yes, it is fast, but the cargo volumes are very small, high cost. Sea transport is very cheap, but if the customer is ready to wait 45 days. Despite the fact that railways are the most economical mode of transport (in contrast to air and road transport), yielding only to pipeline and sea transport costs, the development of iron roads has clearly lagged behind the needs of the national economy.

According to the state program for the development and integration of the infrastructure of the transport system of the Republic of Kazakhstan to 2020, Kazakhstan has clear priorities within the framework of economic development. Creation of the largest trade transit hub in the Central Asian region, building a center where financial services, technical innovations and tourism are concentrated. To reach this aim Kazakhstan plans to invest \$20 billion by 2020 to improve its transport infrastructure. Special attention will be paid to the restoration of transport highways linking the eastern and western regions of Kazakhstan to the Caspian Sea, Azerbaijan, Georgia and Turkey [25].

In addition, Kazakhstan is building the railway Zhezkazgan-Beineu and the 2nd railway line to China. All these routes will allow to send freight railroads of China through the territory of Kazakhstan, to the Persian Gulf and Transcaucasia.

Recently, there has obviously been renewed interest in investing in the creation of new and reconstruction of the existing infrastructure of railways after its polarization for a long period on rolling stock. It is becoming increasingly clear that even the most modern rolling stock can fully realize its technical capabilities if it handles cash flows with a weak track structure that does not match the current load and the speed of the trains.

Energy saving has become the main goal on a global scale, and Europe aims to reduce harmful emissions by $20 \%$ by 2020 compared to 1990 . In the transport sector, the planned activities in the long term focus on planning infrastructure development, modal redistribution of traffic and renewal of rolling stock. European experience shows that the higher payback and political priorities in the preferences of passenger transportation in comparison with freight have a great influence on the level of access fees for the infrastructure. At the same time, it is preferable to develop one-element tariffs for the cargo transportation market, while the passenger transportation market benefits from the efficiency of two-element tariffs.

\section{Conclusion}

Kolomak EA (2011) in his article described the positive efficiency of infrastructure capital. We came to the conclusion that a high level of development of transport and logistics infrastructure in any country has the following positive effects.

1. Decrease in the cost of goods and services. Logistics costs in the cost of goods and services in countries with a high level of logistics development, such as the United States, are estimated at $10 \%$ domestic domestic product, while in countries with undeveloped logistics this figure can reach $20 \%$ or higher.

2. Work creation. Large transport and logistics complexes and logistics centers can be a source of labor for several thousand people. A lot of examples of positive experience in the organization of objects of logistics infrastructure are observed in European countries. In Germany, for example, a network of 31 logistics centers provides jobs for 45,000 people. In Italy, in the logistics centers located in the cities of Padua and Verona, where 2.2 and 1.8 thousand people are provided with work. In Spain, the planned construction of a logistics park Plaza, capable of providing 7 thousand people with new workplaces. In Finland, the total number of employees of the logistics center Avia-Polis, located in the city of Vantaa, is 35 thousand people. In the transport-logistical cluster of Denmark the number of employees is about 3 thousand people.

3. Increase in the turnover of wholesale and retail trade and increase of customer service. International network retailers strive to occupy a niche in the territories with a developed logistics infrastructure, thereby improving the quality of service to the population, which leads to an increase in turnover.

4. Increasing the investment attractiveness of territories with a developed transport and warehouse infrastructure. The influx of private investment leads to an intensification of economic growth and an improvement in the quality of life of the population.

5. Improving the environmental situation is made possible by optimizing the transport infrastructure, which includes the reduction of the rerun of vehicles, the construction of bypass roads around large cities, the separation of freight and passenger flows.

6. Increase in state revenues from the realization of transit potential.

The Silk Road plays a decisive role in the development of transport and logistics infrastructure. Given the considerable length of the territory of Kazakhstan, the level of development of the transport system is especially important. It should be noted that transport has a special role in 
strengthening and developing the country's economy. We can draw the following conclusions.

Firstly, increasing the efficiency of the regional transport and logistics system through the introduction of new technologies. To maintain the traditional railway track on ballast in a proper condition, which corresponds to the modern requirements for the quality of the way for intensive train traffic, considerable investments are required, complex technical means, high labor costs and high qualification of the performers. New types of track structures are suggested, the use of which is believed to simplify the solution of the problem of servicing the track.

Secondly, to increase the efficiency of the use of largecapacity vehicles for long-distance and international cargo by consolidating small lots on terminals in the directions of transportation, reducing the turnover time of the main road trains due to the organization of multi-shift or roundthe-clock operation of the terminals. It is essential to limit access to the city limits for non-Russian heavy-duty road trains.

In the third, to improve the environmental situation in the city by reducing the total number of transport units and their mileage and improve the quality of transport services to the clientele.

In the fourth, significantly improve the efficiency of cargo transportation in international traffic through the introduction of widely used terminal technologies in the world. Including to ensure entry Kazakhstan in the international logistics system of transportation as an equal partner. To develop transportation of transport, in particular by sea transport.

\section{References}

[1] Caves, Christensen Swanson (1980) Economic efficiency of railways and implications for public policy. Journal of Transport Economics and Policy 28(2): 121-138.

[2] Gathon H.J \& Pestieau P (1995) Decomposing efficiency in its managerial and its regulatory components: The case of European railways. European Journal of Operational Research 12: 500-507.

[3] Cowie J \& Riddington G (1996) Measuring the efficiency of European railway. AppliedEconomics 28: 1027-1035.

[4] Bereskin C.G (1996) Econometric estimation of the effects of deregulation on railway productivity growth. Transportation Journal, 34-43.

[5] Berg S, Forsund FR \& Jansen ES (1992) Malmquist indices of labor growth during the deregulation of Norwegian banking 1980-89. Scandinavian Journal of Economics 94: 211-228.

[6] Caves D.W., Christensen L.R \& Swanson J.A (1980) Productivity growth, scale economies and capacity utilization in US railroads, 1955-1974. American Economic Review 71 (December), 994-1002.

[7] Caves D.W., Christensen L.R \& Diewert W.E (1982) The economic theory of index numbers and the measurement of input, output and productivity. Econometrica 50: 1393-1414.

[8] Caves D.W., Christensen L.R., Tretheway M.W \& Windle R.J (1985) Network effects and the measurement of returns to scale and density in US railroads. In: Daugherty (ed) Analytical Studies in Transport Economics (pp. 97-120). Cambridge University Press.

[9] Alchanova R.D. (2009) Development of the system of infrastructural support of entrepreneurial activity. Author's abstract. Ufa [Electronic resource] // Access mode: http:// www.ceninauku.ru/page_11996.htm.

[10] Oveshnikova L.V. (2013) Analysis and ranking of development factors for infrastructure support of entrepreneurial activity [Text] / L.V. Oveshnikov // Audit and financial analysis, No. 5, 2013, pp. 118-122 (0.31 bp).

[11] Fedorov V.N. (2000) Socio-economic potential of the infrastructure: content, evaluation and analysis of development [Text] / V.N. Fedorov. - Ulyanovsk, 2000. - 195 with. Efficiency of entrepreneurial activity [Electronic resource]. Access mode: http: /otherreferats.allbest.ru/economy/00144126_0.html.

[12] Kolomak E.A. (2011) Efficiency of Infrastructure Capital in Russia // Journal of the New Economic Association, 2011, No. 10, pp. 74-93.

[13] Isaev A.G. (2014) State investments as determinants of the economic growth of Russian regions // Regional Studies. 2014, No. 4, pp. 61-72. World Bank [Electronic resource]: Statistical data on the Republic of Kazakhstan - The official website of the World Bank. - Access mode: http://ppi. worldbank.org/explore/ppi_explore.

[14] Lakshmanan T., Andersen W. (2002) Transportation infrastructure, Freight Services. Sector and Economic Growth // Center for Transportation Studies Boston University.

[15] Färe R, Grosskopf S, Morris M \& Zhang Z (1994) Productivity growth, technical progress and efficiency change in industralized countries. American Economic Review 84 (1): 66-83.

[16] Färe R, Grifell-Tatjé E, Grosskopf S \& Lovell CAK (1997) Biased technical change and theMalmquist productivity index. Scandinavian Journal of Economics 99 (1): 119-127.

[17] Leibenstein H. (1996) Allocative efficiency vs 'X-efficiency'. American Economic Review 56: 392-415.

[18] Malmquist S (1953) Index numbers and indifference surfaces, Trabajos de Estadística 4: 209-242.

[19] Oum T.H. and Yu C. (1994) Economic efficiency of railways and implications for public policy. Journal of Transport Economics and Policy 28 (2): 121-138.

[20] Perelman S \& Pestieau. P (1988) Technical performance in public enterprises: A comparative study of railways and postal services. European Economic Review 32: 432-441.

[21] Preston J.M. \& Nash C.A. (1996) El transportepor Ferrocarrilen Europea y el futuro de RENFE. In: José A Herce \& Rus G de (eds), La Regulación de los Transportesen España, 263312, Editorial Civitas.

[22] Vickers J \& Yarrow G (1988) Privatization. An economic analysis. MIT Press, Cambridge, MA. Viton PA (1998) Changes in mutli-mode bus transit efficiency, 1988-1992. Transportation 25: 1-21.

[23] Corinne Blanquart \& Martin Koning (2017) The local economic impacts of high-speed railways: theories and facts.

[24] Savin L. New Silk Road and Eurasian Integration. The Internet-portal "Eye of the Planet", 04.2013.

[25] New Silk Road: strategic interests of Russia and China. Interview with the director of the Center for the Study of Russia and Central Asia Fudan University, Shanghai. INF, 12.2013.URL: http://russiancouncil.ru/inner/?id_4=2883. 
[26] Dergachev V. Will the Eurasian Union be a part of the Chinese superproject? URL: http://dergachev.ru/analit/he Great_Silk_Road/04.html.

[27] Western Europe - Western China. International transit corridor. URL: http://europe-china.kz

[28] strategy2050.kz https://tengrinews.kz/world_news/novyiy-shelkovyiy-put-prolojili-iz-kitaya-v-evropu-330061/

[29] State Program for the Development and Integration of the Infrastructure of the Transport System of the Republic of Kazakhstan to 2020//Decree of the President of the Republic of Kazakhstan of January 13, 2013, No. 725, Astana, 2013.

[30] The economic belt of the Eurasian integration: a report on the ways of implementing the integration project of the integration of the Eurasian Economic Union and the Eco- nomic belt of the Silk Road / [Aliev TM, etc.]. - Moscow: ITI, 2016, $200 \mathrm{p}$.

[31] Zoidov K.KH., Medkov AA, Zoidov Z.K. The development of transit economy is the basis of stability, security and modernization of Russia and the countries of Central Asia / Ed. member corr. RAS V.A. Tsvetkova - M .: CEMI RAS / IPR RAS, 2016, 339 p.

[32] Lukin AV, Luzyanin SG, Li Xin, Denisov IE, Syroezhkin KL, Pyatachkova AS / The head of the team: Lukin A.V. Scientific editor: Yakunin VI Chinese Global Project for Eurasia: Statement of the Problem (analytical report). M.: Scientific expert, 2016, $130 \mathrm{p}$.

[33] Pervukhin V.V., New Silk Road, Scientific public-business magazine "Energy Policy”, No. 3, 2014, Moscow, pp. 18-26. 